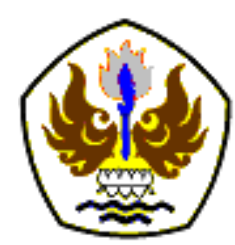

INFOMATEK

Volume 18 Nomor 2 Desember 2016

\title{
ANALISIS RESIKO BENCANA KEBAKARAN DI KOTA BUKITTINGGI
}

\author{
Firmansyah*) \\ Program Studi Perencanaan Wilayah dan Kota \\ Fakultas Teknik - Universitas Pasundan
}

\begin{abstract}
Abstrak: Kota Bukittinggi merupakan salah satu kota di Provinsi Sumatera Barat yang berada di kawasan rawan bencana kebakaran. Penyebab kebakaran yang terjadi di Kota Bukittinggi lebih banyak dipicu oleh bencana gempa bumi, faktor kesalahan manusia dan faktor cuaca. Gempa yang terjadi terkadang sering menimbulkan konslet listrik dan pada akhirnya menyebabkan kebakaran. Melihat potensi bencana yang dimiliki oleh Kota Bukittinggi, menjadikan hal tersebut sebagai isu permasalahan yang harus dipertimbangkan dalam setiap perencanaan pembangunan Kota Bukittinggi, karena bencana dalam bentuk apapun dapat terjadi kapan saja dan dimana saja. Bencana tersebut ada juga yang datang dengan didahului oleh peringatan namun ada juga yang datang secara tiba-tiba, sehingga diperlukan pengelolaan bencana yang lebih sistimatis secara bersamasama baik oleh pemerintah maupun oleh masyarakat. Berdasarkan kondisi Kota Bukittinggi yang memiliki potensi bencana, maka diperlukan studi yang dapat dijadikan masukan dalam upaya mengurangi resiko bencana.Untuk mengurangi resiko tersebut, terlebih dahulu perlu diidentifikasi wilayah-wilayah yang beresiko tinggi kebakaran. Penelitian ini mengacu pada beberapa penelitian sebelumnya dimana ada 3 (tiga) faktor yang mempengaruhi tingkat resiko bencana yaitu faktor bahaya, kerentanan dan ketahanan. Metode analisis yang digunakan pada penelitian ini menggunakan beberapa metode yaitu perhitungan nilai faktor dengan model standarisasi Davidson serta metode superimpose. Selain itu untuk memperoleh tingkat kepentingan faktor-faktor resiko bencana digunakan pembobotan dengan menggunakan metode proses hierarki analitik (Analytical Hierarchy Process/AHP).
\end{abstract}

Kata kunci: Resiko Bencana, Mitigasi Bencana, Bahaya (Hazard), Kota Bukittinggi

\section{PENDAHULUAN}

Kota Bukittinggi merupakan salah satu kota di Provinsi Sumatera Barat yang berada di kawasan rawan bencana kebakaran. Seperti halnya beberapa wilayah kota lain di Indonesia yang memiliki resiko bencana letusan gunung berapi (Rahman, [1]) (Firmansyah, [2]), (Firmansyah, [3]) Kota Bukittinggi tumbuh dan berkembang di sepanjang jalur patahan aktif Sumatera yang

\footnotetext{
*) sangkuriangperfekta@yahoo.com
}

lebih dikenal dengan Ngarai Sianok. Diperkirakan patahan ini bergeser 11 sentimeter per tahun. Kota ini juga dikelilingi oleh dua buah gunung berapi, yaitu Gunung Singgalang dan Gunung Marapi. Kondisi ini menyebabkan secara alamiah Kota Bukittinggi menghadapi bahaya gempa bumi yang dapat memicu bencana gerakan tanah (RTRW Kota Bukittinggi Tahun 2010-2030). 
Tiga topik utama dalam perencanaan adalah States, Markets, dan Provision dari barangbarang sosial. Bencana merupakan salah satu aspek yang harus dikendalikan dalam kaitannya dengan perencanaan suatu wilayah (Campanella, [4]).

Wilayah Pulau Sumatera berada pada daerah subduction yang merupakan pertemuan 2 lempeng kerak bumi aktif/tektonik, yaitu Lempeng Eurasia dan Lempeng IndoAustralia. Pada 6 Maret 2007 gempa melanda wilayah Solok, Tanah Datar dan Bukittinggi. Kejadian gempa tersebut menimbulkan korban jiwa 8 orang meninggal dunia dan mendatangkan kerugian yang sangat besar berupa harta benda serta kerusakan infrastruktur di Kota Bukittinggi.

Penyebab kebakaran yang terjadi di Kota Bukittinggi lebih banyak dipicu oleh bencana gempa bumi, faktor kesalahan manusia dan faktor cuaca. Gempa yang terjadi terkadang sering menimbulkan konslet listrik dan pada akhirnya menyebabkan kebakaran.

Pada tahun 2012 terjadi kebakaran di Kecamatan Aur Birgo Baleh sebanyak 9 kejadian, Kecamatan Guguk Panjang sebanyak 27 kejadian dan Kecamatan Mandiangin Koto Selayan sebanyak 21 kejadian. Perkiraan kerugian yang di derita akibat kebakaran tersebut sekitar Rp.
8.235.257.000. Pada tahun 2013 jumlah kejadian kebakaran sebanyak 13 kejadian, di Kecamatan Mandianin Koto Selayan sebanyak 13 kejadian, dan kejadian kebakaran terbanyak di Kecamatan Guguk Panjang sebanyak 14 kejadian. Kecamatan Guguak Panjang lebih berpotensi atau beresiko tinggi karena kepadatan yang tinggi.

Kepadatan menjadi faktor utama tingginya kerentanan di suatu daerah karena semakin padat suatu daerah maka akan mempermudah api untuk merambat karena struktur bangunan yang padat dan berhimpitan antara bangunan yang satu dengan bangunan yang lainnya. Rata-rata kepadatan penduduk Kota Bukittinggi tahun 2011 adalah 4.500 jiwa $/ \mathrm{km}^{2}$, naik dibandingkan tahun 2010 yang hanya 4,410 jiwa $/ \mathrm{km}^{2}$. Namun kepadatan ini tidak merata di seluruh kecamatan. Kecamatan Guguk Panjang adalah kecamatan terpadat, yakni 6,186 jiwa/km² diikuti Kecamatan Aur Birugo Tigo Baleh 4,039 jiwa/km² dan Kecamatan Mandiangin Koto Selayan 3,789 jiwa/km².

Melihat potensi bencana yang dimiliki oleh Kota Bukittinggi, menjadikan hal tersebut sebagai isu permasalahan yang harus diperimbangkan dalam setiap perencanaan pembangunan Kota Bukittinggi, karena bencana dalam bentuk apapun dapat terjadi kapan saja dan dimana saja. Bencana 
tersebut ada juga yang datang dengan didahului oleh peringatan namun ada juga yang datang secara tiba-tiba, sehingga diperlukan pengelolaan bencana yang lebih sistimatis secara bersama-sama baik oleh pemerintah maupun oleh masyarakat.

Sehubungan dengan hal tersebut, maka perlu dilakukan kajian mengenai Analisis Resiko Bencana kebakaran Kota Bukittinggi, sehingga dapat memberikan panduan operasional pembangunan pada kawasankawasan yang dianggap sebagai kawasan rawan bencana, yang pada akhirnya akan menciptakan rasa aman, nyaman bagi penduduk Kota Bukittinggi untuk tinggal dan beraktivitas.

\section{METODOLOGI}

Awotona memberikan penjelasan mengenai bahaya alam (natural hazard) sebagai berikut :

Natural hazards, as part of our environment, can occur anywhere. Earthquakes, floods, volcanoes and violent weather variations, as well as other extreme natural events, can trigger disaster when they interact with vulnerable conditions (Awotona, [5]).

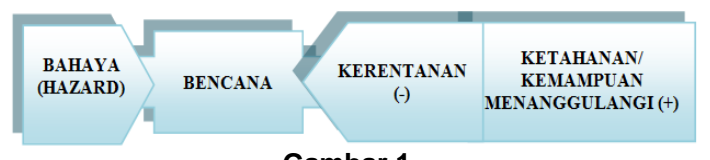

Gambar 1.

Faktor Terjadinya Bencana (Sanderson, [6])
Metode pendekatan yang dilakukan dalam penelitian ini melalui beberapa pentahapan sebagai berikut:

1. Perumusan faktor dan sub faktor yang mempengaruhi tingkat resiko bencana kebakaran. Faktor dan sub faktor ini ditentukan berdasarkan penelitian literatur. Faktor yang berpengaruh terhadap tingkat resiko bencana kebakaran terdiri atas tiga faktor, yaitu: faktor bahaya (hazard), faktor kerentanan (vulnerability) dan faktor ketahanan/ kapasitas (capacity).

2. Selanjutnya dilakukan perumusan indikator-indikator resiko dari setiap subsub faktor yang sebelumnya telah dirumuskan, berdasarkan pengkajian literatur.

3. Penentuan bobot dari tiap faktor, sub faktor dan indikator yang telah terbentuk dengan menggunakan proses hierarki analitik (Analitycal Hierarchy Process/ AHP).

4. Melakukan perhitungan nilai resiko bencana kebakaran yang terdiri atas tiga faktor yaitu bahaya, kerentanan dan ketahanan.

5. Melakukan perhitungan indeks resiko dan merumuskan tingkat resiko bencana kebakaran dan untuk setiap kelurahan di seluruh wilayah Kota Bukittinggi. 
Berdasarkan penjelasan atas analisis-analisis yang digunakan akan diuraikan pada bagian berikut ini:

A. Analisis Faktor Bahaya (Hazard), Faktor Kerentanan (Vulnerability), dan Faktor Ketahanan (Capacity)

a. Standarisasi Nilai Indikator, nilai indikator dimaksudkan untuk menghasilkan nilai baku, sehingga dapat dilakukan perhitungan matematis dengan indikator yang lain dengan model standarisasi yang digunakan untuk indikator yang nilainya bersesuaian dengan resiko bencana.

b. Pembobotan Faktor, Sub Faktor dan Indikator, pembobotan dilakukan untuk menghasilkan nilai resiko bencana karena setiap faktor dan sub faktor bencana memberikan kontribusi yang berbeda terhadap bencana dengan menggunakan proses hierarki analitik (Analytical Hierarchy Process/ AHP).

C. Perhitungan Nilai Faktor-Faktor Bencana, setelah indikator-indikator setiap faktor resiko bencana distandarkan (dibakukan), maka dilakukan perhitungan nilai/indeks resiko bencana. Rumus yang digunakan untuk menghitung nilai setiap faktor resiko bencana adalah:

$$
\begin{array}{ll}
\mathrm{B} & =\mathrm{W}_{\mathrm{B} 1} \mathrm{X}_{\mathrm{B} 1}^{\prime}+\ldots \ldots \ldots \ldots+\mathrm{W}_{\mathrm{Bn}} \mathrm{X}_{\mathrm{Bn}}^{\prime} \\
\mathrm{R} & =\mathrm{W}_{\mathrm{R} 1} \mathrm{X}_{\mathrm{R} 1}^{\prime}+\ldots \ldots \ldots \ldots+\mathrm{W}_{\mathrm{Rn}} \mathrm{X}_{\mathrm{Rn}}^{\prime}
\end{array}
$$

$\mathrm{K}=\mathrm{W}_{\mathrm{K} 1} \mathrm{X}_{\mathrm{K} 1}^{\prime}+\ldots \ldots \ldots . .+\mathrm{W}_{\mathrm{Kn}} \mathrm{X}_{\mathrm{Kn}}^{\prime}$

Dimana :

$\mathrm{B}=$ Nilai Faktor Bahaya (hazards)

$\mathrm{R}=$ Nilai Faktor Kerentanan

(Vulnerability)

$\mathrm{K}=$ Nilai Faktor

Ketahanan/Kapasitas (Capacity)

$X^{\prime}{ }_{i}=$ Nilai Setiap Indikator yang telah

dibakukan

$\mathrm{W}_{\mathrm{i}}=$ Bobot Setiap Indikator

\section{B. Teknik Superimpose dan Skoring}

Metode ini digunakan untuk analisis data spasial non administratif, dengan menggunakan analisis pada beberapa layer data spasial yang mewakili setiap indikator analisis.

Penelitian ini mengacu pada beberapa penelitian sebelumnya dimana ada 3 (tiga) faktor yang mempengaruhi tingkat resiko bencana yaitu faktor bahaya, kerentanan dan ketahanan. Metode analisis yang digunakan pada penelitian ini menggunakan beberapa metode yaitu perhitungan nilai faktor dengan model standarisasi Davidson serta metode superimpose (Davidson, [7]). Selain itu untuk memperoleh tingkat kepentingan faktor-faktor resiko bencana digunakan pembobotan dengan menggunakan metode proses hierarki analitik (Analytical Hierarchy Process/AHP). 
Tabel 1

Faktor, Sub Faktor dan Indikator Tingkat Resiko Bencana Berdasarkan Jenis Bencana

\begin{tabular}{|c|c|c|c|}
\hline No & Faktor & Sub Faktor & $\begin{array}{c}\text { Indikator (Berdasarkan Jenis } \\
\text { BencanaKebakaran }\end{array}$ \\
\hline A & $\begin{array}{l}\text { Bahaya } \\
\text { (Hazard) }\end{array}$ & $\begin{array}{l}\text { Rawan } \\
\text { Bencana }\end{array}$ & $\begin{array}{l}\text { - Rawan Bencana Kebakaran Tinggi } \\
\text { - Rawan Bencana Kebakaran Sedang } \\
\text { - Rawan Bencana Kebakaran Rendah }\end{array}$ \\
\hline \multirow[t]{3}{*}{$B$} & \multirow[t]{3}{*}{$\begin{array}{l}\text { Kerentanan } \\
\text { (Vulnerability) }\end{array}$} & $\begin{array}{l}\text { Kerentanaan } \\
\text { Fisik }\end{array}$ & $\begin{array}{l}\text { - Kepadatan Bangunan } \\
\text { - Kondisi Fisik Bangunan }\end{array}$ \\
\hline & & $\begin{array}{l}\text { Kerentanan } \\
\text { Sosial } \\
\text { Kependudukan }\end{array}$ & $\begin{array}{l}\text { - Kepadatan Penduduk } \\
\text { - \% Penduduk Wanita } \\
\text { - \% Penduduk Tua \& Balita }\end{array}$ \\
\hline & & $\begin{array}{l}\text { Kerentanan } \\
\text { Ekonomi }\end{array}$ & - Pusat Kegiatan Ekonomi \\
\hline \multirow[t]{2}{*}{ C } & \multirow[t]{2}{*}{$\begin{array}{l}\text { Ketahanan } \\
\text { (Capacity) }\end{array}$} & $\begin{array}{l}\text { Sumberdaya } \\
\text { Buatan }\end{array}$ & $\begin{array}{l}\text { - Rasio Lapangan : Penduduk } \\
\text { - Rasio RTH : Penduduk } \\
\text { - Rasio Tempat Evakuasi : Penduduk } \\
\text { - Rasio Fasilitas Kesehatan : Penduduk } \\
\text { - Rasio Dokter : Penduduk } \\
\text { - Jumlah Hidrant }\end{array}$ \\
\hline & & Mobilitas & Aksesibilitas \\
\hline
\end{tabular}

\section{HASIL DAN PEMBAHASAN}

Posisi Kota Bukittinggi terletak antara 110 20'$100^{\circ} 25^{\prime}$ BT dan $00^{\circ} 16^{\prime}-00^{\circ} 20^{\prime}$ LS dengan ketinggian 780-950 $\mathrm{m}$ dari permukaan laut, luas daerah lebih kurang $25.239 \mathrm{Km}^{2}$ merupakan $0,06 \%$ dari luas Provinsi Sumatera Barat, Kota Bukittingi terdiri dari 3 Kecamatan dan 24 Kelurahan. Kota Bukittinggi secara administratif berbatasan dengan :

- Utara : Nagari Gadut kec.Tilatang Kamang Kab.Agam.

- Selatan :Taluak Nagari IV Suku Kec Banuhampu Kab Agam.

- Timur : Tanah Alam Nagri Biaro Gadang Kec IV Angkek Canduang Kab Agam.

- Barat : Nagari Sianok dan Koto Gadang Kec IV Koto Kab Agam.
Untuk menghitung tingkat resiko bencana dilakukan dengan menghitung tingkat kerentanan dan tingkat ketahanan dengan menggunakan statistik dan dengan bantuan perangkat lungak GIS (Geographic Information System), resiko bencana alam di Kota Bukittinggi dihitung berdasarkan jenis bencana di Kota Bukittinggi yang meliputi bencana kebakaran. Pada tahun 2013 jumlah kejadian kebakaran sebanyak 13 kejadian, di Kecamatan Mandianin Koto Selayan sebanyak 13 kejadian, dan kejadian kebakaran terbanyak di Kecamatan Guguk Panjang sebanyak 14 kejadian. Kecamatan Guguak Panjang lebih berpotensi atau beresiko tinggi karena kepadatan yang tinggi. Kepadatan menjadi faktor utama tingginya kerentanan di suatu daerah karena semakin padat suatu daerah maka akan 
mempermudah api untuk merambat karena struktur bangunan yang padat dan berhimpitan antara bangunan yang satu dengan bangunan yang lainnya. Rata-rata kepadatan penduduk Kota Bukittinggi tahun 2011 adalah 4.500 jiwa $/ \mathrm{km}^{2}$, naik dibandingkan tahun 2010 yang hanya 4,410 jiwa/km². Namun kepadatan ini tidak merata di seluruh kecamatan. Kecamatan Guguk Panjang adalah kecamatan terpadat, yakni 6,186 jiwa/km² diikuti Kecamatan Aur Birugo Tigo Baleh 4,039 jiwa/km² dan Kecamatan Mandiangin Koto Selayan 3,789 jiwa/km². Melalui analisis maka didapatkan hasil seperti terlihat pada Tabel 2.

Tabel 2

Analisis Bahaya Kebakaran

\begin{tabular}{|c|c|c|c|c|}
\hline \multirow{2}{*}{ No } & \multirow{2}{*}{ Kecamatan/Kelurahan } & \multicolumn{2}{|c|}{ Kejadian Kebakaran 2014} & \multirow{2}{*}{ Kategori } \\
\hline & & $\begin{array}{c}\text { Jumlah } \\
\text { Kejadian }\end{array}$ & Nilai Baku & \\
\hline & Kecamatan Guguak Panjang & & & \\
\hline 1 & Bukik Cangang Kayu Ramang & 1 & 13.46 & Tinggi \\
\hline 2 & Tarok Dipo & 1 & 13.46 & Tinggi \\
\hline 3 & Pakan Kurai & 1 & 13.46 & Tinggi \\
\hline 4 & Aur Tajungkang Tengah Sawah & 1 & 13.46 & Tinggi \\
\hline 5 & Benteng Pasar Atas & 1 & 13.46 & Tinggi \\
\hline 6 & Kayu Kubu & 1 & 13.46 & Tinggi \\
\hline \multirow[t]{2}{*}{7} & Bukit Apit Puhun & & & \\
\hline & Kecamatan Mandiangin Koto selayan & & & \\
\hline 8 & Pulai Anak Air & & & \\
\hline 9 & Koto Selayan & & & \\
\hline 10 & Garegeh & & & \\
\hline 11 & Maggih Ganting & 1 & 13.46 & Tinggi \\
\hline 12 & Campago Ipuh & 1 & 13.46 & Tinggi \\
\hline 13 & Puhun Tembok & 1 & 13.46 & Tinggi \\
\hline 14 & Puhun Pintu Kabun & & & \\
\hline 15 & Kubu Gulai Bancah & & & \\
\hline \multirow[t]{2}{*}{16} & Campago Guguk Bulek & & & \\
\hline & Kecamatan Aur Birugo Tigo Baleh & & & \\
\hline 17 & Belakang Balok & 1 & 13.46 & Tinggi \\
\hline 18 & Sapiran & 1 & 13.46 & Tinggi \\
\hline 19 & Birugo & 1 & 13.46 & Tinggi \\
\hline 20 & Aur Kuning & 1 & 13.46 & Tinggi \\
\hline 21 & Pakan Labuah & & & \\
\hline 22 & Kubu Tanjung & & & \\
\hline 23 & Ladang Cangkiah & & & \\
\hline \multirow[t]{2}{*}{24} & Parit Antang & & & \\
\hline & $\begin{array}{l}\text { Nilai Rata rata Xi } \\
\text { Standar Deviasi }\end{array}$ & $\begin{array}{c}0.541667 \\
0.04\end{array}$ & & \\
\hline
\end{tabular}


Di Kota Bukittinggi masih banyak bangunan yang terbuat dari kayu sehingga sangat rentan terhadap bencana kebakaran. Perhitungan tingkat kerentanan kebakaran dapat diidentifikasi melalui beberapa variabel yaitu angka kepadatan bangunan, dan bangunan yang terbuat dari kayu. Untuk perhitungan nilai tingkat kerentanan bencana kebakaran dihitung berdasarkan nilai rata-rata maka dapat di klasifikasikan 0,77-1,52 tingkat kerentanan rendah, 1,53-2,281 tingkat kerentanan sedang, dan 2,29-3,04 Tingkat kerentanan Tinggi. Untuk lebih jelasnya dapat dilihat pada Tabel 3.

Kapasitas dari bencana kebakaran dibedakan karena melihat ketersediaan sumber air dalam tanggap darurat bencana kebakaran. Analisis ini menggunakan ketersediaan reservoir di kelurahan dalam menanggulangi bencana kebakaran.

Tabel 3

Analisis Tingkat Kerentanan Bencana Kebakaran

\begin{tabular}{|c|c|c|c|c|c|c|c|c|c|c|}
\hline \multirow[b]{2}{*}{ No } & \multirow[b]{2}{*}{$\begin{array}{l}\text { Kecamatan } \\
\text { /Kelurahan }\end{array}$} & \multicolumn{3}{|c|}{ Kepadatan Bangunan } & \multicolumn{3}{|c|}{ Bangunan Kayu } & \multirow[b]{2}{*}{$\begin{array}{l}\text { Aksesi- } \\
\text { bilitas }\end{array}$} & \multirow[b]{2}{*}{$\begin{array}{l}\text { Nilai } \\
\text { Baku }\end{array}$} & \multirow[b]{2}{*}{ Kategor } \\
\hline & & $\begin{array}{c}\text { Angka } \\
\text { Kepadatan }\end{array}$ & $\begin{array}{l}\text { Nilai } \\
\text { Baku }\end{array}$ & $\begin{array}{l}\text { Bobot } \\
(x 0.50)\end{array}$ & $\begin{array}{c}\% \\
\text { Bangunan } \\
\text { Kayu }\end{array}$ & $\begin{array}{l}\text { Nilai } \\
\text { Baku }\end{array}$ & $\begin{array}{l}\text { Bobot } \\
(\times 0.50)\end{array}$ & & & \\
\hline A & \multicolumn{10}{|c|}{ Kecamatan Guguak Panjang } \\
\hline 1 & $\begin{array}{l}\text { Bukik Cangang Kayu } \\
\text { Ramang }\end{array}$ & 13 & 0,82 & 0,41 & 0,2 & 0,72 & 0,36 & Rendah & 0,77 & Rendah \\
\hline 2 & Tarok Dipo & 118 & 3,73 & 1,87 & 0,3 & 2,06 & 1,03 & Tinggi & 2,9 & Tinggi \\
\hline 3 & Pakan Kurai & 73 & 2,49 & 1,25 & 0,4 & 3,39 & 1,69 & Tinggi & 2,94 & Tinggi \\
\hline 4 & $\begin{array}{l}\text { Aur Tajungkang } \\
\text { Tengah Sawah }\end{array}$ & 108 & 3,47 & 1,73 & 0,3 & 2,06 & 1,03 & Tinggi & 2,76 & Tinggi \\
\hline 5 & Benteng Pasar Atas & 112 & 3,57 & 1,78 & 0,3 & 2,06 & 1,03 & Tinggi & 2,81 & Tinggi \\
\hline 6 & Kayu Kubu & 40 & 1,56 & 0,78 & 0,4 & 3,39 & 1,69 & Tinggi & 2,47 & Tinggi \\
\hline 7 & Bukit Apit Puhun & 26 & 1,19 & 0.60 & 0,4 & 3,39 & 1,69 & Tinggi & 1,69 & Sedang \\
\hline B & \multicolumn{10}{|c|}{ Kecamatan Mandiangin Koto selayan } \\
\hline 8 & Pulai Anak Air & 57 & 2,04 & 1,02 & 0,3 & 2,06 & 1,03 & Tinggi & 2,05 & Sedang \\
\hline 9 & Koto Selayan & 18 & 0,96 & 0,48 & 0,2 & 0,72 & 0,36 & Rendah & 0,84 & Rendah \\
\hline 10 & Garegeh & 38 & 1,51 & 0,75 & 0,2 & 0,72 & 0,36 & Rendah & 1,11 & Rendah \\
\hline 11 & Maggih Ganting & 74 & 2,53 & 1,26 & 0,4 & 3,39 & 1,69 & Tinggi & 2,95 & Tinggi \\
\hline 12 & Campago Ipuh & 70 & 2,4 & 1,2 & 0,2 & 0,72 & 0,36 & Rendah & 1,56 & Sedang \\
\hline 13 & Puhun Tembok & 92 & 3 & 1,5 & 0,3 & 2,06 & 1,03 & Tinggi & 2,53 & Sedang \\
\hline 14 & Puhun Pintu Kabun & 18 & 0,96 & 0,48 & 0,3 & 2,06 & 1,03 & sedang & 1,51 & Rendah \\
\hline 15 & Kubu Gulai Bancah & 30 & 1,3 & 0,65 & 0,3 & 2,06 & 1,03 & sedang & 1,68 & Sedang \\
\hline
\end{tabular}




\begin{tabular}{|c|c|c|c|c|c|c|c|c|c|c|}
\hline \multirow[b]{2}{*}{ No } & \multirow[b]{2}{*}{$\begin{array}{l}\text { Kecamatan } \\
\text { /Kelurahan }\end{array}$} & \multicolumn{3}{|c|}{ Kepadatan Bangunan } & \multicolumn{3}{|c|}{ Bangunan Kayu } & \multirow[b]{2}{*}{$\begin{array}{c}\text { Aksesi- } \\
\text { bilitas }\end{array}$} & \multirow[b]{2}{*}{$\begin{array}{l}\text { Nilai } \\
\text { Baku }\end{array}$} & \multirow[b]{2}{*}{ Kategori } \\
\hline & & $\begin{array}{c}\text { Angka } \\
\text { Kepadatan }\end{array}$ & $\begin{array}{l}\text { Nilai } \\
\text { Baku }\end{array}$ & $\begin{array}{l}\text { Bobot } \\
(\times 0.50)\end{array}$ & $\begin{array}{c}\% \\
\text { Bangunan } \\
\text { Kayu }\end{array}$ & $\begin{array}{l}\text { Nilai } \\
\text { Baku }\end{array}$ & $\begin{array}{l}\text { Bobot } \\
(x 0.50)\end{array}$ & & & \\
\hline 16 & $\begin{array}{l}\text { Campago Guguk } \\
\text { Bulek }\end{array}$ & 39 & 1,54 & 0,77 & 0,2 & 0,72 & 0,36 & sedang & 1,13 & Rendah \\
\hline C & \multicolumn{10}{|c|}{ Kecamatan Aur Birugo Tigo Baleh } \\
\hline 17 & Belakang Balok & 58 & 2,08 & 1,04 & 0,4 & 3,39 & 1,69 & Tinggi & 2,73 & Tinggi \\
\hline 18 & Sapiran & 127 & 3,99 & 1,99 & 0,3 & 2,06 & 1,03 & Tinggi & 3,02 & Tinggi \\
\hline 19 & Birugo & 65 & 2,56 & 1,13 & 0,4 & 3,39 & 1,69 & Tinggi & 2,82 & Tinggi \\
\hline 20 & Aur Kuning & 76 & 2,57 & 1,28 & 0,3 & 2,06 & 1,03 & Tinggi & 2,31 & Sedang \\
\hline 21 & Pakan Labuah & 24 & 1,13 & 0,56 & 0,3 & 2,06 & 1,03 & sedang & 1,59 & Sedang \\
\hline 22 & Kubu Tanjung & 15 & 0,87 & 0,43 & 0,3 & 2,06 & 1,03 & sedang & 1,46 & Rendah \\
\hline 23 & Ladang Cangkiah & 24 & 1,13 & 0,57 & 0,2 & 0,72 & 0,36 & sedang & 0,93 & Rendah \\
\hline 24 & Parit Antang & 16 & 0,9 & 0,45 & 0,2 & 0,72 & 0,36 & sedang & 0,81 & Rendah \\
\hline & Nilai Rata rata $\mathrm{Xi}$ & 5.544 .018 & & & 0,2958 & & & & & \\
\hline & Standar Deviasi & 3.606 .346 & & & 0,0751 & & & & & \\
\hline
\end{tabular}

Keterangan : 0,77-1,52 tingkat kerentanan rendah, 1,53-2,281 tingkat kerentanan sedang, dan 2,29-3,04 Tingkat kerentanan Tinggi

Variabel lain yang digunakan adalah lahan kosong, lapangan, Ruang Terbuka Hijau (RTH, serta Emergency Respon seperti bantuan langsung yang dapat diterima dari aparat seperti TNI ataupun relawan.
Dengan menggunakan variabel tersebut diatas maka hasil analisis yang dilakukan adalah seperti yang ditunjukkan pada Tabel 4 .

Tabel 4

Kapasitas Bencana Kebakaran untuk Parameter, Lapangan, Reservoar dan Tempat Evakuasi

\begin{tabular}{|c|c|c|c|c|c|c|c|c|c|c|}
\hline \multirow[b]{2}{*}{ No } & \multirow{2}{*}{$\begin{array}{c}\text { Kecamatan/ } \\
\text { Kelurahan }\end{array}$} & \multicolumn{3}{|c|}{ Lapangan } & \multicolumn{3}{|c|}{ Reservoar } & \multicolumn{3}{|c|}{ Tempat Evakuasi } \\
\hline & & Jumlah & $\begin{array}{l}\text { Nilai } \\
\text { Baku }\end{array}$ & $\begin{array}{l}\text { Bobot } \\
(\times 0.20)\end{array}$ & Jumlah & $\begin{array}{l}\text { Nilai } \\
\text { Baku }\end{array}$ & $\begin{array}{l}\text { Bobot } \\
(x 0.10)\end{array}$ & Jumlah & $\begin{array}{l}\text { Nilai } \\
\text { Baku }\end{array}$ & $\begin{array}{l}\text { Bobot } \\
(x 0.20)\end{array}$ \\
\hline 1 & Kecamatan Guguak Panjang & 1 & 4,25 & 0,85 & 4 & 4,31 & 0,86 & 2 & 8,35 & 1,67 \\
\hline 2 & $\begin{array}{l}\text { Kecamatan Mandiangin Koto } \\
\text { selayan }\end{array}$ & 1 & 4,25 & 0,85 & 0 & 2,58 & 0,52 & 2 & 8,35 & 1,67 \\
\hline 3 & $\begin{array}{l}\text { Kecamatan Aur Birugo Tigo } \\
\text { Baleh }\end{array}$ & 1 & 4,25 & 0,85 & 0 & 2,58 & 0,52 & 1 & 6,62 & 1,32 \\
\hline & Jumlah & 3 & & & 4 & & & 5 & & \\
\hline & Nilai Rata rata $\mathbf{X i}$ & 1 & & 0,2 & 133.333 & & 0,2 & 16.667 & & 0,2 \\
\hline & Standar Deviasi & 0,89 & & & 2,31 & & & 0,58 & & \\
\hline
\end{tabular}


Tabel 5

Kategori Bencana Kebakaran untuk Faskes, Jumlah Dokter, Jumlah Hidran serta Parameter Lainnya

\begin{tabular}{|c|c|c|c|c|c|c|c|c|c|c|c|c|}
\hline \multirow[b]{2}{*}{ No } & \multirow{2}{*}{$\begin{array}{l}\text { Kecamatan/ } \\
\text { Kelurahan }\end{array}$} & \multicolumn{3}{|c|}{ Fasilitas Kesehatan } & \multicolumn{3}{|c|}{ Jumlah Dokter } & \multicolumn{3}{|c|}{ Jumlah Hidran } & \multirow{2}{*}{$\begin{array}{c}\text { Nilai Rata- } \\
\text { rata }\end{array}$} & \multirow{2}{*}{ Kategori } \\
\hline & & Jumlah & $\begin{array}{l}\text { Nilai } \\
\text { Baku }\end{array}$ & $\begin{array}{l}\text { Bobot } \\
(x 0.20)\end{array}$ & Jumlah & $\begin{array}{l}\text { Nilai } \\
\text { Baku }\end{array}$ & $\begin{array}{l}\text { Bobot } \\
(x 0.20)\end{array}$ & Jumlah & $\begin{array}{l}\text { Nilai } \\
\text { Baku }\end{array}$ & $\begin{array}{l}\text { Bobot } \\
(x 0.10)\end{array}$ & & \\
\hline 1 & Kecamatan Guguak Panjang & 2 & 8,35 & 1,67 & 362,33 & 4 & 0,8 & 1 & 4,25 & 0,425 & 6,28 & Tinggi \\
\hline 2 & $\begin{array}{l}\text { Kecamatan Mandiangin Koto } \\
\text { selayan }\end{array}$ & 2 & 8,35 & 1,67 & 362,33 & 4 & 0,8 & 1 & 4,25 & 0,425 & 5,94 & Sedang \\
\hline 3 & $\begin{array}{l}\text { Kecamatan Aur Birugo Tigo } \\
\text { Baleh }\end{array}$ & 1 & 6,62 & 1,32 & 362,33 & 4 & 0,8 & 1 & 4,25 & 0,425 & 5,24 & Rendah \\
\hline & Jumlah & 5 & & & 1087 & & & 3 & & & & \\
\hline & Nilai Rata rata $\mathbf{X i}$ & 1.666 .667 & & 0.2 & 36.233 .333 & & 0,2 & 1 & & & & \\
\hline & Standar Deviasi & 0,58 & & & 0 & & & 0,89 & & & & \\
\hline
\end{tabular}

Catatan: 5,24-5,59 tingkat kapasitas rendah, 5,60-5,95 tingkat kapasitas sedang, dan 5,96-6,31 Tingkat kapasitasTinggi

Dari hasil analisis tingkat resiko bencana kebakaran di Kota Bukittinggi yang memiliki tingkat resiko bencana paling tinggi berada pada Kelurahan Bukit Cangang Kayu
Ramang.Ramang, Tarok Dipo, Benteng Pasar Atas, Kayu Kubu, dan lain-lain. Untuk lebih jelasnya dapat dilihat pada Tabel 6 .

Tabel 6.

Analisis Tingkat Resiko Bencana Kebakaran

\begin{tabular}{|c|c|c|c|c|c|c|c|c|c|}
\hline \multirow[b]{2}{*}{ No } & \multirow[b]{2}{*}{$\begin{array}{l}\text { Kecamatan } \\
\text { /Kelurahan }\end{array}$} & \multicolumn{2}{|r|}{ Bahaya } & \multicolumn{2}{|c|}{ Kerentanan } & \multicolumn{2}{|c|}{ Ketahanan } & \multirow[b]{2}{*}{$\begin{array}{c}\text { Nilai } \\
\text { Indeks } \\
\text { Resiko }\end{array}$} & \multirow[b]{2}{*}{$\begin{array}{l}\text { Tingkat } \\
\text { Resiko } \\
\text { Bencana }\end{array}$} \\
\hline & & Nilai & $\begin{array}{l}\text { Nilai x Bobot } \\
\text { Bahaya }(0,50)\end{array}$ & Nilai & $\begin{array}{c}\text { Nilai } x \text { Bobot } \\
\text { Kerentanan } \\
(0,25)\end{array}$ & Nilai & \begin{tabular}{|c|} 
Nilai $x$ Bobot \\
Ketahanan \\
$(0,25)$
\end{tabular} & & \\
\hline A & \multicolumn{9}{|l|}{ Kecamatan Guguak Panjang } \\
\hline 1 & Bukik Cangang Kayu Ramang & 13,46 & 6,73 & 0,77 & 0,19 & 6,28 & 1,57 & 8,49 & Tinggi \\
\hline 2 & Tarok Dipo & 13,46 & 6,73 & 2,9 & 0,73 & 6,28 & 1,57 & 9,02 & Tinggi \\
\hline 3 & Pakan Kurai & 13,46 & 6,73 & 2,94 & 0,74 & 6,28 & 1,57 & 9,03 & Tinggi \\
\hline 4 & Aur Tajungkang Tengah Sawah & 13,46 & 6,73 & 2,76 & 0,69 & 6,28 & 1,57 & 8,99 & Tinggi \\
\hline 5 & Benteng Pasar Atas & 13,46 & 6,73 & 2,81 & 0,70 & 6,28 & 1,57 & 9,00 & Tinggi \\
\hline 6 & Kayu Kubu & 13,46 & 6,73 & 2,47 & 0,62 & 6,28 & 1,57 & 8,92 & Tinggi \\
\hline 7 & Bukit Apit Puhun & & & 1,69 & 0,42 & 6,28 & 1,57 & 1,99 & Rendah \\
\hline
\end{tabular}




\begin{tabular}{|c|c|c|c|c|c|c|c|c|c|}
\hline \multirow[b]{2}{*}{ No } & \multirow[b]{2}{*}{$\begin{array}{l}\text { Kecamatan } \\
\text { /Kelurahan }\end{array}$} & \multicolumn{2}{|r|}{ Bahaya } & \multicolumn{2}{|c|}{ Kerentanan } & \multicolumn{2}{|c|}{ Ketahanan } & \multirow[b]{2}{*}{$\begin{array}{c}\text { Nilai } \\
\text { Indeks } \\
\text { Resiko }\end{array}$} & \multirow[b]{2}{*}{\begin{tabular}{|c} 
Tingkat \\
Resiko \\
Bencana
\end{tabular}} \\
\hline & & Nilai & $\begin{array}{l}\text { Nilai } x \text { Bobot } \\
\text { Bahaya }(0,50)\end{array}$ & Nilai & $\begin{array}{c}\text { Nilai x Bobot } \\
\text { Kerentanan } \\
(0,25)\end{array}$ & Nilai & $\begin{array}{c}\text { Nilai x Bobot } \\
\text { Ketahanan } \\
(0,25)\end{array}$ & & \\
\hline B & \multicolumn{9}{|c|}{ Kecamatan Mandiangin Koto selayan } \\
\hline 8 & Pulai Anak Air & & & 2,05 & 0,51 & 5,94 & 1,48 & 2,00 & Rendah \\
\hline 9 & Koto Selayan & & & 0,84 & 0,21 & 5,94 & 1,48 & 1,69 & Rendah \\
\hline 10 & Garegeh & & & 1,11 & 0,28 & 5,94 & 1,48 & 1,76 & Rendah \\
\hline 11 & Maggih Ganting & 13,46 & 6,73 & 2,95 & 0,74 & 5,94 & 1,48 & 8,95 & Tinggi \\
\hline 12 & Campago Ipuh & 13,46 & 6,73 & 1,56 & 0,39 & 5,94 & 1,48 & 8,60 & Tinggi \\
\hline 13 & Puhun Tembok & 13,46 & 6,73 & 2,53 & 0,63 & 5,94 & 1,48 & 8,85 & Tinggi \\
\hline 14 & Puhun Pintu Kabun & & & 1,51 & 0,38 & 5,94 & 1,48 & 1,86 & Rendah \\
\hline 15 & Kubu Gulai Bancah & & & 1,68 & 0,42 & 5,94 & 1,48 & 1,90 & Rendah \\
\hline 16 & Campago Guguk Bulek & & & 1,13 & 0,28 & 5,94 & 1,48 & 1,77 & Rendah \\
\hline C & \multicolumn{9}{|c|}{ Kecamatan Aur Birugo Tigo Baleh } \\
\hline 17 & Belakang Balok & 13,46 & 6,73 & 2,73 & 0,68 & 5,24 & 1,31 & 8,72 & Tinggi \\
\hline 18 & Sapiran & 13,46 & 6,73 & 3,02 & 0,76 & 5,24 & 1,31 & 8,79 & Tinggi \\
\hline 19 & Birugo & 13,46 & 6,73 & 2,82 & 0,71 & 5,24 & 1,31 & 8,74 & Tinggi \\
\hline 20 & Aur Kuning & 13,46 & 6,73 & 2,31 & 0,58 & 5,24 & 1,31 & 8,62 & Tinggi \\
\hline 21 & Pakan Labuah & & & 1,59 & 0,40 & 5,24 & 1,31 & 1,71 & Rendah \\
\hline 22 & Kubu Tanjung & & & 1,46 & 0,37 & 5,24 & 1,31 & 1,67 & Rendah \\
\hline 23 & Ladang Cangkiah & & & 0,93 & 0,23 & 5,24 & 1,31 & 1,54 & Rendah \\
\hline 24 & Parit Antang & & & 0,81 & 0,20 & 5,24 & 1,31 & 1,51 & Rendah \\
\hline
\end{tabular}

Keterangan : 1,51-4,01 tingkat resiko rendah, 4,02-6,52 tingkat resiko sedang, 6,53-9,03 tingkat resiko tinggi

Hasil analisis tingkat resiko bencana kebakaran di Kota Bukittinggi yang terjabar dalam Tabel 6 ini dapat ditampilkan dalam peta yang terlihat pada Gambar 2. 


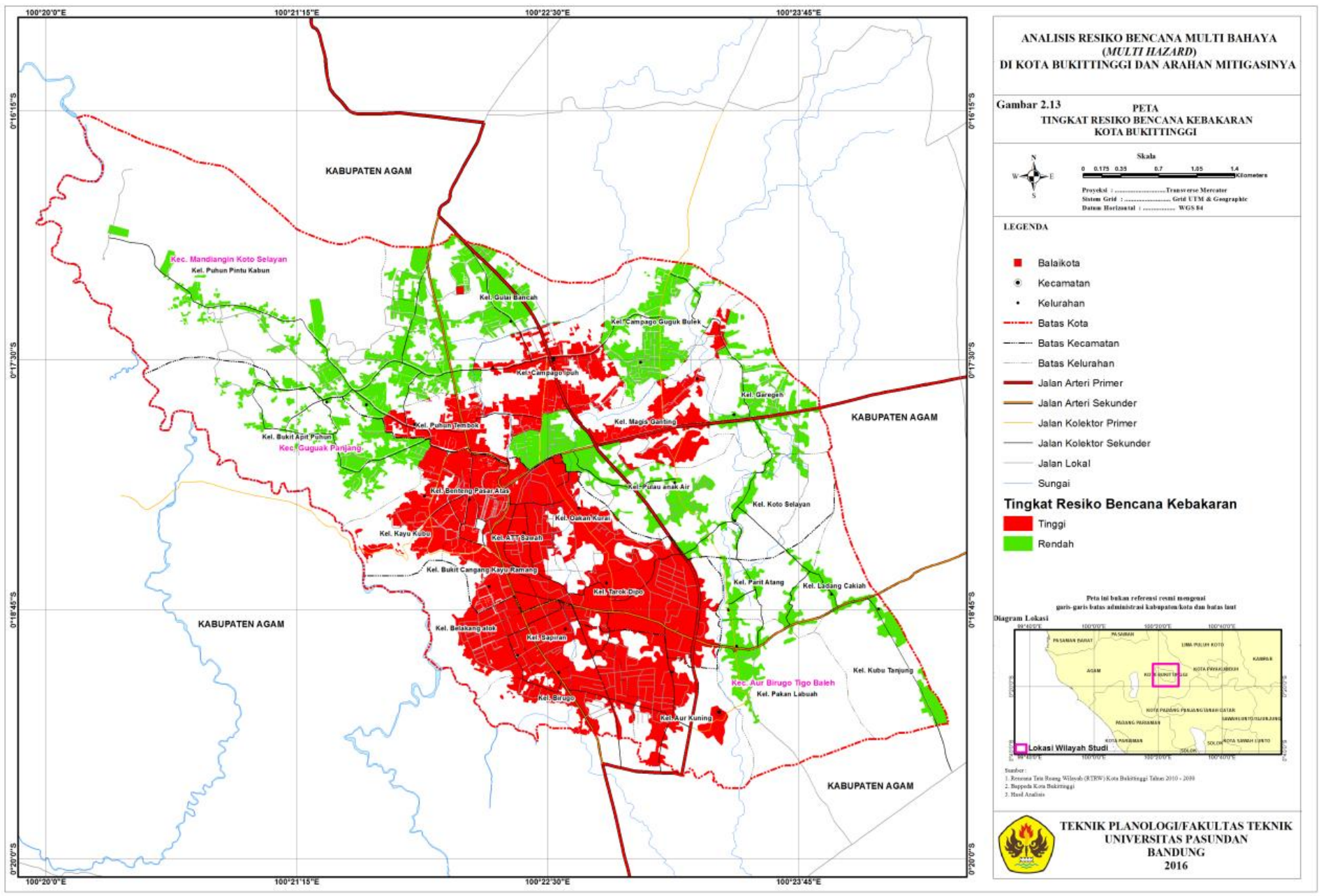

Gambar 2.

Tingkat resiko bencana kebakaran Kota Bukittinggi 


\section{KESIMPULAN}

Hasil penelitian menunjukkan bahwa lokasi kawasan rawan bencana kebakaran ditetapkan berdasarkan klaster, yang meliputi: klaster Bukik Cangang Kayu Ramang, Klaster Tarok Dipo, Klaster Pakan Kurai, Klaster Air Tajungkang Tengah Sawah, Klaster Benteng Pasar Atas, Klaster Bukit Kayu Kubu, Klaster Maggih Ganting, Klaster Campago Ipu, Klaster Puhun Tembok, Klaster Belakang Balok, Klaster Sapiran, Klaster Birugo dan Klaster Aur Kuninng.

Adapun arahan mitigasi bencana kebakaran di Kota Bukittinggi adalah sebagai berikut:

1. Hidran dan pembuatan reservoar

2. Hidran porttable

3. Pembuatan jalur akses cepat tanggap terhadap kebakaran

\section{DAFTAR PUSTAKA}

[1] Rahman R, Firmansyah, Oktariadi, (2010). Penentuan Tingkat Resiko Bencana Letusan Gunung Gamalama Pulau Ternate Provinsi Maluku Utara., Buletin Geologi Tata Lingkungan vol.20 No.3 Desember 2010. Pusat Lingkungan Geologi, Badan Geologi, Kementerian Energi dan Sumberdaya Mineral.

[2] Firmansyah, (2011). Identifikasi Tingkat Resiko Bencana Letusan Gunung
Gamalama di Kota Ternate. Jurnal Lingkungan dan Bencana Geologi. ISSN 2086-7794 vol.2 No.3 Desember 2011. Bandung. Badan Geologi Kementerian Energi dan Sumberdaya Mineral.

[3] Firmansyah (1998). Identifikasi Risiko Bencana Gempa Bumi dan Implikasinya Terhadap Penataan Ruang di Kotamadya Daerah Tingkat II Bandung. Tesis: Program Studi Perencanaan Wilayah dan Kota Institut Teknologi Bandung.

[4] Campanella, Thomas J. and Godschalk, David R (2012). Resilience. the Oxford Handbook of Urban Planning. Weber, Rachel and Crane, Randall. Oxfor: Oxfor University Press.

[5] Awotona, Adenrele (1997). Reconstruction After Disaster : Issues and Practices. Aldershot: Ashgate.

[6] Sanderson, David (1997). Building Bridges to Reduce Risk. Dalam Reconstruction After Disaster : Issues and Practices. Awotona, Adenrale (ed) (1997). Aldershot: Ashgate.

[7] Davidson, Rachel A (1997). An Urban Earthquake Disaster Risk Index. Stanford: The John A. Blume Earthquake Engineering Center, Department of Civil Engineering Stanford University. 